\title{
Pre-Service Teacher's Beliefs and Knowledge about Mathematics
}

\author{
Muhtarom $^{1}$, Nurina Happy ${ }^{2}$, Farida Nursyahidah ${ }^{3}$, Anriany Casanova ${ }^{4}$ \\ ${ }^{1,2,3}$ Program Studi Pendidikan Matematika Universitas PGRI Semarang \\ ${ }^{4}$ National Chung Hsing University, Taiwan \\ ${ }^{1}$ Correspondence Address; muhtarom@upgris.ac.id
}

\begin{abstract}
This research describes the knowledge and beliefs of pre-service teachers about mathematics. Data collection of this research using written test of 143 mathematics pre-service teachers who have taken six semesters at Universitas PGRI Semarang, and interviewing of three pre-service teachers who are not consistent between knowledge and belief. The data are presented in the form of descriptive quantitative and analyzed qualitatively, including data reduction, data display, and conclusions drawing/verification. The results show that most of the knowledge of pre-service teachers are consistent with their beliefs. It is indicated that pre-service teachers' knowledge has been internalized into a strong belief that affect their words and behaviors. The belief of almost half of pre-service teachers who become respondents changes because of lecturer activity effect. It can say that belief changes at any time, both the process of alteration and the formation of new beliefs as well as the reinforcement of the beliefs they have.
\end{abstract}

Keywords: Beliefs; Knowledge; Pre-Service Teacher's, Mathematics

\section{INTRODUCTION}

Research on beliefs has attracted much attention from educators. The educational paradigm has shifted from behaviorism to constructivist. Constructivists emphasize that the next steps and the minds of people are primarily based on their ideas that are previously built. Muhtarom, Juniati, \& Siswono, (2017a) and Siswono, Kohar, \& Hartono, (2017) have summarized the opinions of some researchers in categorizing beliefs, which are divided into instrumentalist, platonist and constructivist. In general, instrumentalist's beliefs view mathematics as a collection of facts, rules, and formulas used in solving problems. Mathematics is considered a set of unrelated but useful rules and facts. Platonist's beliefs view mathematics as integrated science, relating to strongly intertwined structures and truths, and one another is bound by logic and meaning. While constructivist beliefs view mathematics as something dynamic, the space of human discovery that develops continuously and then filtered into knowledge (Beswick, 2012; Ernest, 1989; Muhtarom, Juniati, \& Siswono, 2017a; Thompson, 1992). There are three descriptors namely the definition of mathematics, the development of mathematics, and the relationship of mathematics with everyday life that can be used to explore beliefs on mathematics (Muhtarom, Juniati, \& Siswono, 2018).

Beliefs are parts of highly subjective knowledge and on the other hand feelings and beliefs are often overlapping and difficult to distinguish. Beliefs and knowledge can be interchangeable; when students are asked "what is mathematics?", they answer by expressing their views on the nature of mathematics which can be called with beliefs about mathematics (Amirali \& Halai, 2010; Felbrich, Kaiser, \& Schmotz, 2012). Cognitive structure pertaining to the mathematical beliefs is hidden in the person but the symptoms usually appear when he performs mathematical work, interacts with the classroom environment, or responds to a stimulus. The school environment is very influential on the beliefs owned by students (Eynde, 
Corte, \& Verschaffel, 2002). Beliefs reflects the individual's philosophy on the nature of knowledge and how to acquire it which influences the decision-making. Mathematical beliefs can be considered as individual perspectives on how to engage in math tasks and pedagogical practices (Mkomange \& Ajegbe, 2012; Muhtarom, Juniati, \& Siswono, 2017b).

The above description shows there is a link between one's beliefs and knowledge. Related to the difference between belief and knowledge, Thompson (1992) explains that truth is associated as knowledge, while beliefs have disagreements since there is no agreement. Thus, belief is characterized by the lack of agreement on how something is justified. A belief based on the passage of time can be accepted as a knowledge that can encourage the emergence of new theories. One's beliefs do not necessarily correspond to the beliefs of others. In the case of knowledge, one will not accept different situations (Furinghetti \& Pehkonen, 2002; Thompson, 1992). This shows how important the beliefs in mathematics. Pre-service teachers who later become professional teachers should also have the knowledge and beliefs on mathematics that are consistent, not different.

This is very important because the consistency between knowledge and beliefs is a value in prospective teachers so that it really affects every word, behavior, and action in the future. Based on the description above, the purpose of this research was to describe the knowledge and beliefs of pre-service teachers to mathematics.

\section{THE RESEARCH METHODS}

\section{General Background of Research}

This research is very important to be studied in more depth because it provides the consistency of knowledge and beliefs pre-service teachers so that it becomes the basis to develop pre-service teacher's beliefs. The consistency between knowledge and belief was a value that could affect every person's words, behavior, and actions.

\section{Sample of Research}

The participants in this research were 143 mathematics pre-service teachers who were in six semesters at Universitas PGRI Semarang during the academic year 2017/2018. The participants were purposely chosen given the following criteria: 1) the research participants had in-depth beliefs and knowledge about mathematics, 2) the participant who were not consistent between knowledge and beliefs, and 3) considered to possess good communication skills.

\section{Instrument and Procedures}

The data in the research were collected directly by the researcher, assisted by supporting instruments, in the form of a written test and interview guideline. Prior to use, the research instruments were validated in advance by three experts of validation and the validity results of instruments showed that they were feasible to be used for research data retrieval. Data were collected was held in April and May 2018. The written test contained a number of open questions to reveal pre-service teachers knowledge and beliefs about mathematics. The questions are the following:

Describe your knowledge and beliefs to math! 
Describe your knowledge and beliefs about the relationship of mathematical topics to everyday life!

Describe your knowledge and beliefs about the development of mathematical knowledge from the past to the present time!

Have your beliefs in math ever changed? When and what factors do influence it?

Based on the results of questionnaire analysis given to students of mathematics preservice teacher, it was generally found that $74.13 \%$ or 106 students had instrumentalist beliefs; 24 students had platonist beliefs and 13 students had constructivist beliefs (Table 1). Furthermore, three students who were not consistent between knowledge and beliefs were selected purposively, and further interviews were conducted to provide an in-depth description of the knowledge and beliefs of pre-service teachers to math. We chose Winoto (male, pseudo name) a student who tended to have instrumentalist beliefs, Satria (male, pseudo name) a student who tended to have platonist beliefs, and Pujiasih (female, pseudo name) a student who tended to have constructivist beliefs. Interviews were conducted twice at different times. Then, the first interview and the second interview data were in the triangle to get valid data.

\section{Data Analysis}

Quantitative data analysis was presented to describe the percentage of pre-service teachers' knowledge and beliefs and qualitative data analysis done by data reduction technique, data presentation and conclusion (Miles \& Huberman, 1992). These three data analysis activities were not hierarchical but were interwoven interrelated activities from before, during and after data collection.

\section{THE RESULTS OF THE RESEARCH AND THE DISCUSSION}

The majority of mathematics pre-service teachers who had instrumentalist beliefs consistently had knowledge with what they believed that was to view mathematics as exact science that included numbers, counts, and symbols, and there were 10 pre-service teachers who were different between their knowledge and beliefs. Table 1 clearly explains that there were 22 pre-service teachers believed that mathematics was as the arithmetic to solve problems, 55 pre-service teachers believed that mathematics was an exact science to solve problems; and 29 pre-service teachers viewed mathematics as the science of numbers, symbols, agreements, and logic. Furthermore, $73.5 \%$ or 78 pre-service teachers had unchanging beliefs during their lectures at Universitas PGRI Semarang; while there were 28 pre-service teachers experienced a change of belief in mathematics. $80 \%$ of the beliefs changes were caused by lecturers of philosophy course and $20 \%$ were caused by reading references.

Table 1. Description of Beliefs

\begin{tabular}{llcl}
\hline $\begin{array}{l}\text { Beliefs } \\
\text { Categories }\end{array}$ & Description & $\begin{array}{c}\text { Percentage } \\
(\mathbf{\%})\end{array}$ & Change of Beliefs \\
\hline Instrumentalist & $\begin{array}{l}\text { Mathematics as the arithmetic } \\
\text { to solve the problem }\end{array}$ & 20.75 & $\begin{array}{l}73.5 \% \text { of pre-service } \\
\text { teachers have relatively } \\
\text { fixed beliefs, and } 26.5 \%\end{array}$ \\
$\begin{array}{l}\text { Mathematics as an exact } \\
\text { science to solve problems }\end{array}$ & 51.89 & &
\end{tabular}




\begin{tabular}{|c|c|c|c|}
\hline $\begin{array}{l}\text { Beliefs } \\
\text { Categories }\end{array}$ & Description & $\begin{array}{c}\text { Percentage } \\
(\%)\end{array}$ & Change of Beliefs \\
\hline \multirow{3}{*}{ Platonist } & $\begin{array}{l}\text { Mathematics as the science of } \\
\text { numbers, symbols, agreements } \\
\text { and logic }\end{array}$ & 27.36 & $\begin{array}{l}\text { of pre-service teachers } \\
\text { change their beliefs. }\end{array}$ \\
\hline & $\begin{array}{l}\text { Mathematics deals with other } \\
\text { materials }\end{array}$ & 16.67 & \multirow{3}{*}{$\begin{array}{l}54.2 \% \text { of pre-service } \\
\text { teachers have relatively } \\
\text { fixed beliefs and } 45.8 \% \\
\text { of pre-service teachers } \\
\text { change their beliefs. }\end{array}$} \\
\hline & $\begin{array}{l}\text { Mathematics as a science } \\
\text { related to daily life and related } \\
\text { between concepts }\end{array}$ & 29.17 & \\
\hline & $\begin{array}{l}\text { Mathematics as a collection of } \\
\text { symbols related to each other } \\
\text { Mathematics as interrelated } \\
\text { static knowledge. }\end{array}$ & 37.50 & \\
\hline Constructivist & $\begin{array}{l}\text { The science that man creates } \\
\text { through agreements, continues } \\
\text { to grow and be useful in } \\
\text { everyday life }\end{array}$ & 100 & $\begin{array}{l}46.15 \% \text { of pre-service } \\
\text { teachers have relatively } \\
\text { fixed beliefs and } 53.85 \% \\
\text { of pre-service teachers } \\
\text { change their beliefs. }\end{array}$ \\
\hline
\end{tabular}

Whereas from 24 pre-service teachers who had platonist beliefs, there were 17 pre-service teachers who consistently had knowledge with what they believed, 2 pre-service teachers had knowledge in viewing mathematics as a science of numbers, and 5 pre-service teachers viewed mathematics as an exact science with regard to reasoning. It is clearly described in Table 1 that there were 7 pre-service teachers who believed mathematics as a science related to daily life and related among the concepts, 9 pre-service teachers believed mathematics as a collection of related symbols with each other, and 4 pre-service teachers believed in mathematics as interlinked static knowledge. Furthermore, it was shown that there were 13 pre-service teachers who had unchanging beliefs during the lecture at Universitas PGRI Semarang, and 11 preservice teachers experienced a change of beliefs in mathematics caused by lecturer of philosophy subject. Specifically pre-service teachers who had constructivist beliefs, who believed in math was a science created by humans through agreements, constantly evolved and were useful in daily life to solve math problems. There were 7 pre-service teachers who consistently had knowledge with what they believed, and the rest had the knowledge in viewing mathematics as an exact science that included numbers, counts and symbols. The results of this research also showed that there were 6 pre-service teachers who had unchanging beliefs during lectures at Universitas PGRI Semarang; while 7 pre-service teachers experienced a change of beliefs in mathematics caused by lecturer of philosophy subject.

To get a deeper description of the inconsistency between the pre-service teacher's knowledge and beliefs, one subject was chosen from each of the beliefs categories, to be interviewed to provide an in-depth picture of the pre-service teachers' knowledge and beliefs toward mathematics. 


\section{Winoto 's knowledge and beliefs about mathematics}

It is obvious Figure 1 shows that Winoto had different knowledge and beliefs about mathematics definition. Mathematics was a collection of definition, axiom, theorem that had been invented by advanced mathematicians that was mutually sustainable that could be used to solve problems in everyday life. The word 'sustainable' meant interconnected among definition, axiom or theorem but was useful for accomplishing tasks in everyday life. However Winoto believed that mathematics was an exact science that was closely related to numbers. This opinion reflected a mathematics view that consisted of a collection of static facts, methods, and rules needed to find answers to specific tasks. Winoto asserted that what he believed as the definition of mathematics never changed. Associated with the relationship of mathematics with everyday life, subject had knowledge that math was used in everyday life such as buying and selling process. Although Winoto understood that math had something to do with everyday life because he found the concept of counting or estimating to set an alarm to make him not late for school in the morning; this did not mean that subject had beliefs that mathematics arose as a result of necessity in everyday situations. This was in line with the subject's statement about the relationship of mathematics to everyday life that never changed because from the beginning until now mathematics is used and applied in everyday life.

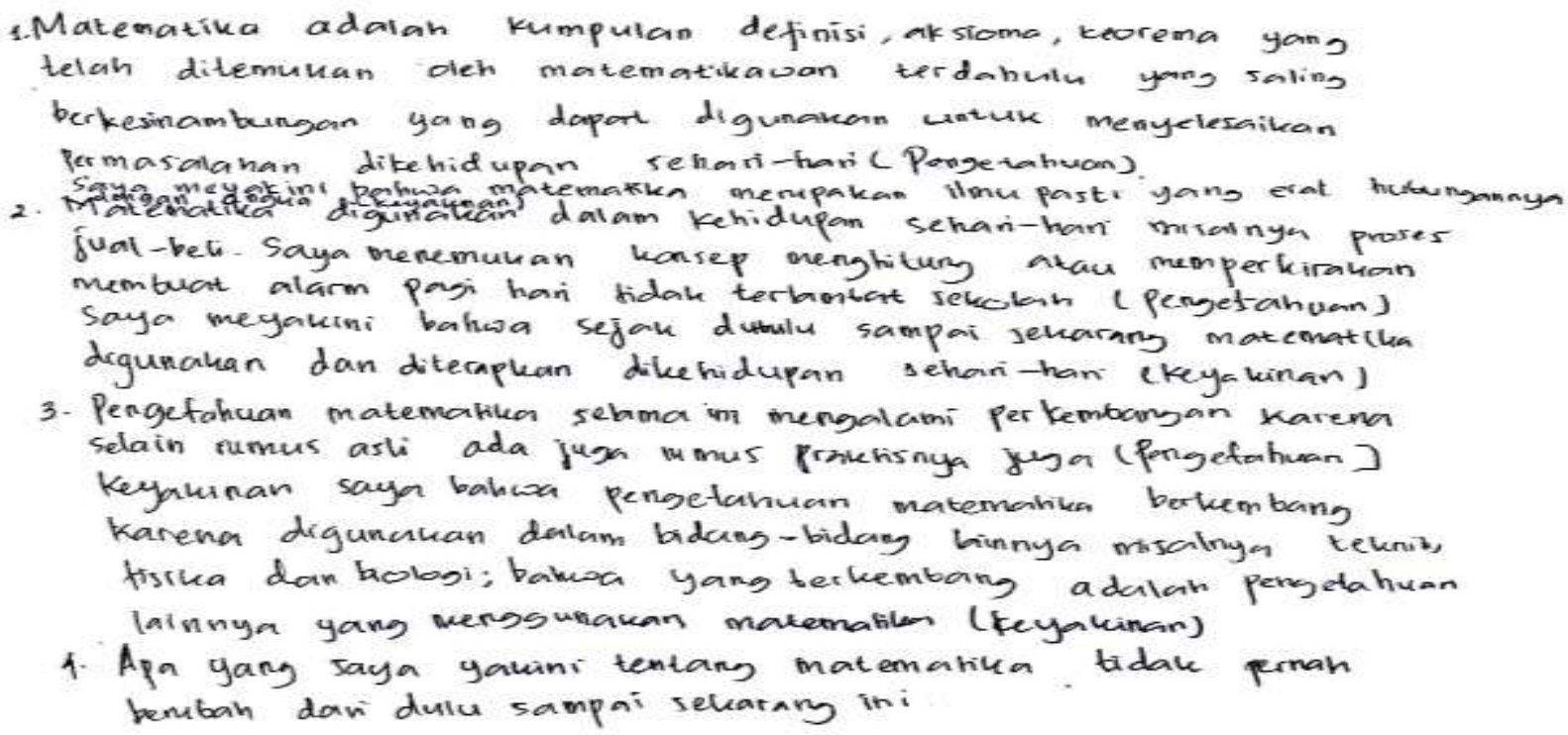

Figure 1. Winoto 's Written Work

Winoto understood that mathematical knowledge had been progressing since in addition to the original formulas there were also practical formulas as well, but this understanding implied that mathematical knowledge was predicted absolute, fixed, unchanging and undeveloped. Something which developed was only a way of solving the problems of mathematics itself. It was like his beliefs that mathematical knowledge developed because it was used in other fields such as engineering, physics and biology; something that developed was another knowledge that used mathematical knowledge. Based on the description above 
Winoto's beliefs on the nature of mathematics was largely in harmony with instrumentalist beliefs, especially when the subject stated about the mathematics that was closely related to numbers. Certainty was the inherent quality on mathematical activities. The procedure and method used in mathematics guaranteed the correct answer. In line with his beliefs, mathematical knowledge was predicted to be absolute, fixed, did not much change and used to solve problems in everyday life.

\section{Satria 's knowledge and beliefs about mathematics}

It is clearly Figure 2 shows that Satria had different knowledge and beliefs about mathematics definition. Mathematics was a very universal science, was the basis of technology and had an important role in life; and could also be used for everything. The word 'important role' meant useful for solving problems in everyday life. Satria believed that mathematics was an exact science that formed the basis of other sciences. This opinion reflected the views of mathematics that interconnected with other fields of science. What he believed to be the definition of mathematics had changed, and it was influenced by the lecturer. First, Satria believed that mathematics was concerned only with counting, memorizing and formulas. Associated with the relationship of mathematics to everyday life, Satria had knowledge that mathematics was used in everyday life. Mathematics had to do with everyday life. This was in line with his beliefs that the relationship of mathematics to everyday life never changed because from the beginning until now mathematics was used and applied in everyday life.

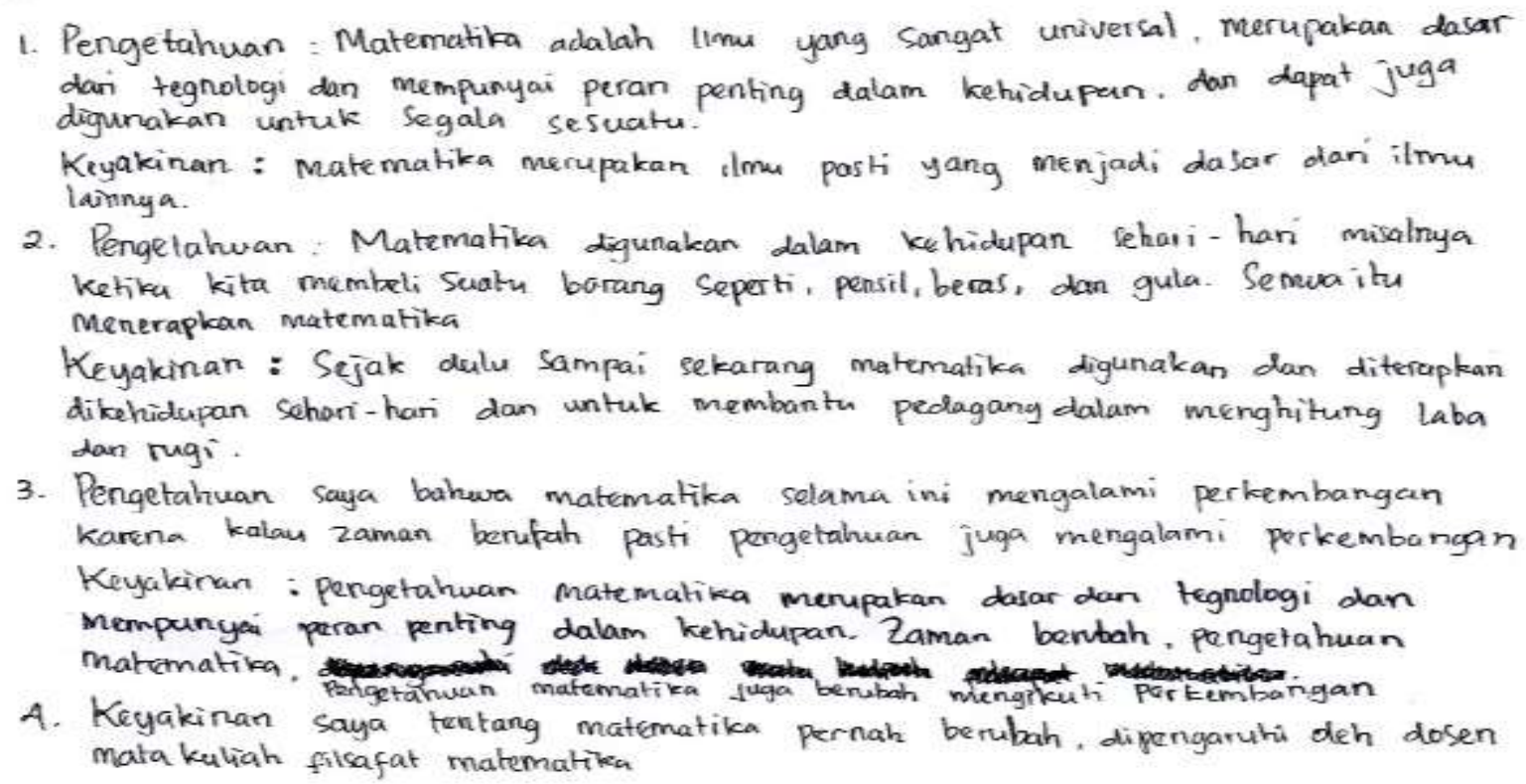

Figure 2. Satria 's Written Work

Satria had knowledge and beliefs about the development of the same mathematical knowledge. Subject understood and believed that the knowledge of mathematics had been progressing because if time changed, knowledge must also develop; this opinion implied that 
the knowledge of mathematics developed and human beings only found the mathematical concept itself. Based on the description above Satria's beliefs on mathematics was largely in line with platonist beliefs, especially when the subject stated about mathematics as exact science that became the foundation of other sciences. One needed to master mathematical concepts and understood the relationship between mathematical concepts because mathematics had a deductive and consistent mindset of truth. In line with his choice, it emphasized that mathematics was the basis of technology and had an important role in life; and could also be used for everything.

\section{Pujiasih 's knowledge and beliefs about mathematics}

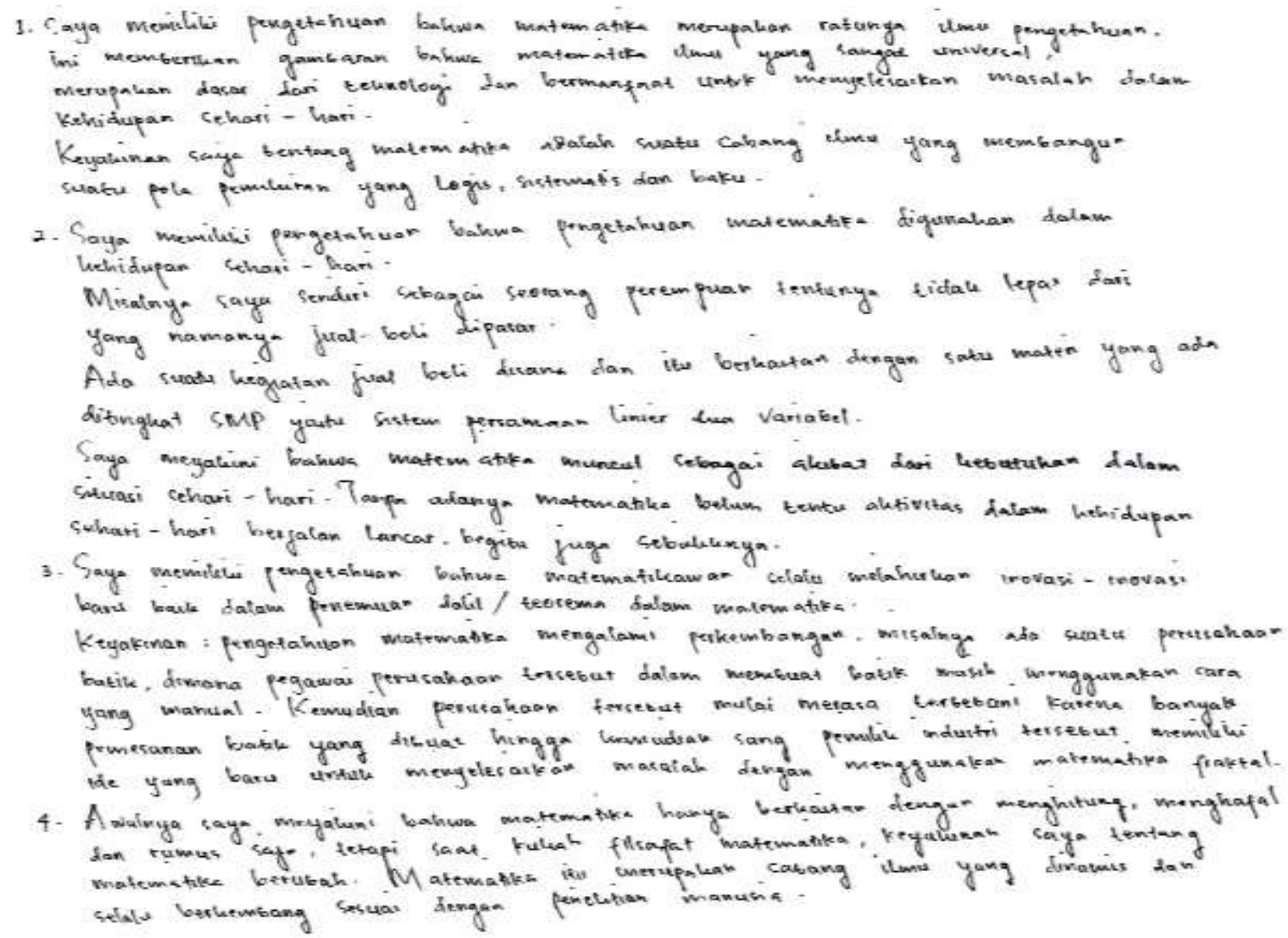

Figure 3. Pujiasih 's Written Work

It is obvious Figure 3 shows that Pujiasih had different knowledge and beliefs about mathematics definition. Mathematics was the queen of knowledge, this gave the idea that mathematics was a science that was very universal, was the basis of technology and useful for solving problems in everyday life. Then Pujiasih believed that mathematics was a branch of science that built a logical, systematic and standardized pattern of thought. Pujiasih asserted that what she believed to be the definition of mathematics had changed, and it was influenced by a lecturer. First, the subject believed that mathematics dealt only with counting, memorizing and formulas only. Associated with the relationship of mathematics to everyday life, the subject 
had knowledge that mathematics was used in everyday life. Pujiasih had beliefs that mathematics arose as a result of necessity in everyday situations. This was in line with her beliefs that if there was no mathematics, the activities in everyday life did not run smoothly, and vice versa. It showed that the subject already understood that mathematics developed due to problems in everyday life. Then mathematics was used to solve the problem. The subject had knowledge and beliefs about the same development of mathematical knowledge that was mathematicians always created new innovations in the discovery of theorems/theorems in mathematics. Based on the description above, her beliefs in mathematics was in harmony with the constructivist beliefs; she believed that mathematicians always created new innovations both in the discovery of theorems/theorems in mathematics.

It was clear that the results of the research indicated that there was the knowledge that was not believed to be beliefs by some mathematics pre-service teachers, whereas the consistency between knowledge and beliefs was a value that could affect every word, behavior, and actions of pre-service teachers. This was reinforced by Artzt (1999) and Leder \& Forgasz (2002) who state that belief is as a system integrated with knowledge and its goal influences the practice of mathematics learning. Belief is as an inevitable interaction between thought and feeling. On one hand, belief is part of a highly subjective knowledge, and on the other hand, feeling and belief are often overlapping and difficult to distinguish.

The results also showed that there was a change of beliefs held by students. This change was influenced by themselves and the environment, especially the lecture activity by the lecturer, so that it could change whenever every person experienced the formation, alteration or reinforcement of his/her beliefs. The process of formation of the beliefs of a student is influenced by the process of interaction with the student's social system, and especially the classroom environment that is encountered on the occasion of every learning activity (Muhtarom, Juniati, Siswono, \& Rahmatika, 2018). This is reinforced by Eynde, Corte, \& Verschaffel (2002) who state that mathematics education, the class context, and him/herself, simultaneously influence mathematical beliefs. The three aspects are mutually related to each other in forming mathematical beliefs in students. Beliefs reflect the individual's philosophy of the nature of knowledge and how to acquire it which in turn affects the decision-making and learning approaches undertaken. Teacher's mathematical beliefs can be considered as individual perspectives on how to engage in math tasks and pedagogical practices (Mkomange \& Ajegbe, 2012; Muhtarom, Juniati, \& Siswono, 2017b). Muhtarom, Juniati, \& Siswono (2017b) explains that a large number of university pre-service students to become mathematics teachers who hold platonist views is due to their mathematics experience at school, and university courses have also strengthened these beliefs. Belief is an important thing that must be instilled in children early on as it can be the basis for disposition, the basis for action, the basis for change and the basis for learning (Chapman, 2015).

Furthermore this discussion has reinforced the views of some previous researchers, for example (Amirali \& Halai, 2010; Beswick, 2012; Ernest, 1989; Felbrich, Kaiser, \& Schmotz, 2012; Muhtarom, Juniati, \& Siswono, 2017a; Siswono, Kohar, \& Hartono, 2017; Thompson, 1992). Instrumentalist beliefs believe that mathematics is a set of tools made of a set of facts, 
rules that are not interrelated but useful (Ernest, 1989); mathematics is such as the set of unrelated but useful rules and facts (Muhtarom, Juniati, \& Siswono, 2017a). Platonist beliefs believe in mathematics as a static system of a set of rules, concepts, and theorems (Felbrich, Kaiser and Schmotz, 2012; Thompson, 1992) and Muhtarom, Juniati, \& Siswono (2018) states that mathematics is found, not created. Thus the existence of mathematics can be used to solve problems in everyday life. While constructivist beliefs believe mathematical knowledge continues to evolve according to the pattern of discovery and the results remain open for revision (Ernest, 1989). Felbrich, Kaiser, \& Schmotz (2012) explains the problem is found together in a mathematical topic then used to solve problems on the mathematical topic itself as well as other daily life issues.

\section{CONCLUSION AND SUGGESTION}

The majority of mathematics pre-service teachers who are instrumentalists consistently have knowledge with what they believe namely viewing mathematics as exact science that includes numbers, counts and symbols. Furthermore, from 24 platonist mathematics pre-service teachers there are 17 pre-service teachers who consistently have knowledge with what they believe, and 13 pre-service teachers of constructive mathematics teachers are 7 pre-service teachers who consistently have knowledge with what they believe, the rest have different knowledge and belief. Lecturers should facilitate the formation of pre-service teacher's knowledge and beliefs towards constructivist in accordance with the demands of the curriculum in Indonesia.

\section{REFERENCES}

Amirali, M., \& Halai, A. (2010). Teachers' knowledge about the nature of mathematics: A Survey of Secondary school teachers in Karachi, Pakistan. Bulletin of Education and Research, 32(2), 45-61.

Artzt, A. F. (1999). A structure to enable preservice teachers of mathematics to reflect on their teaching. Journal of Mathematics Teacher Education, 2(2), 143-166.

Beswick, Kim. (2012). Teachers' beliefs about school mathematics and mathematicians' mathematics and their relationship to practice. Educational Studies in Mathematics, 79(1), 127-147.

Chapman, O. (2015). Mathematics teachers' knowledge for teaching problem solving. LUMAT, $3(1), 19-36$.

Ernest, P. (1989). The Impact of Beliefs on the Teaching of Mathematics. Science and Technology Education, 35, 99-101.

Eynde, Peter Op't. Corte, E.D, dan Verschaffel, L. (2002). Framing Students' MathematicsRelated Belief. A Quest for Conseptual Clarity and a Comprehensive Categorization. dalam Gilah, L. C, Erkki, P dan Gunter, T. (ed). Belief: A Hidden Variable in Mathematics Education?. Dordrecht: Kluwer Academic Publishers. 
Felbrich, A., Kaiser, G., \& Schmotz, C. (2012). The cultural dimension of beliefs: An investigation of future primary teachers' epistemological beliefs concerning the nature of mathematics in 15 countries. ZDM Mathematics Education, 44(3), 355-366.

Furinghetti, F., \& Pehkonen, E. (2002). Rethinking characterizations of belief. In G. Leder, E. Pehkonen \& G. Törner (Eds.), Beliefs: A hidden variable in mathematics education? (pp. 39-57). Dordrecht: Kluwer Academic Publisher.

Leder, G. C, \& Forgasz, H. J. (2002). Measuring mathematical belief and their impact on the learning of mathematics: A new approach. In G. C.Leider, E. Pehkonen, dan G. Torner (ed). Beliefs: A Hidden Variable in Mathematics Education? Dordrecht: Kluwer Academic Publisher.

Miles, M., \& Huberman, A. M. (1992). Analisis Data Kualitatif: Buku Sumber Tentang MetodeMetode Baru (Qualitative Data Analysis: The Source Book about New Methods). Jakarta: UI Press.

Mkomange, W.C \& Ajegbe, M.A. (2012). Prospective secondary teachers' beliefs about mathematical problem solving. International Journal of Research in Management \& Technology, 2(2), 154-163.

Muhtarom, Juniati, D., \& Siswono, T.Y.E. (2017a). Consistency and inconsistency of prospective teachers' beliefs in mathematics, teaching, learning and problem solving. In AIP Conference Proceedings (Vol. 1868, p. 050014). AIP Publishing. Retrieved from http://aip.scitation.org/doi/abs/10.1063/1.4995141.

Muhtarom, Juniati, D., \& Siswono, T.Y.E. (2017b). Exploring Beliefs in a Problem-Solving Process of Prospective Teachers' With High Mathematical Ability. Global Journal of Engineering Education, 19(2), 130-136.

Muhtarom, Juniati, D., \& Siswono, T.Y.E. (2018). Exploring Prospective Teachers' Beliefs about Nature of Mathematics. Journal of Engineering and Applied Sciences, 13(10), 1547 3554.

Muhtarom, Juniati, D., Siswono, T.Y.E., \& Rahmatika, Ismi (2018). Teachers' and students' beliefs in mathematics of the State Senior High School 5 Semarang. Jurnal Riset Pendidikan Matematika, 5(1), 65-72.

Siswono, T. Y. E., Kohar, A. W., \& Hartono, S. (2017). Secondary Teachers' Mathematicsrelated Beliefs and Knowledge about Mathematical Problem-solving. In Journal of Physics: Conference Series (Vol. 812, p. 012046). IOP Publishing. Retrieved from http://iopscience.iop.org/article/10.1088/1742-6596/812/1/012046/meta

Thompson, A. G. (1992). Teachers' Beliefs and Conceptions: A synthesis of the research. In D. A. Grouws (Ed.), Handbook of research on mathematics teaching and learning. Reston, VA: National Council of Teachers of Mathematics. Retrieved from http://psycnet.apa.org/psycinfo/1992-97586-007. 